\title{
Dry matter intake and body condition score change of dairy cows grazing fodder beet, kale and kale-oat forage systems in winter
}

\author{
G.R. EDWARDS ${ }^{1}$, J. M. de RUITER ${ }^{2}$, D. E. DALLEY ${ }^{3}$, J.B. PINXTERHUIS ${ }^{3}$, K.C. CAMERON ${ }^{1}$, \\ R.H. BRYANT ${ }^{1}$, H.J. DI ${ }^{1}$; B.J. MALCOLM ${ }^{1}$ and D.F CHAPMAN ${ }^{3}$ \\ ${ }^{1}$ Faculty of Agriculture and Life Sciences, PO Box 85084, \\ Lincoln University, Lincoln 7647, Christchurch, New Zealand \\ ${ }^{2}$ Plant \& Food Research, Private Bag 4704, Christchurch Mail Centre, Christchurch, 8140, New Zealand \\ ${ }^{3}$ DairyNZ, Canterbury Agriculture \& Science Centre, Gerald St, PO Box 85066, \\ Lincoln University 7647, Canterbury, New Zealand \\ grant.edwards@lincoln.ac.nz
}

\begin{abstract}
Crop dry matter (DM) yield, DM utilisation and body condition score (BCS) of dairy cows were measured over two winters on an irrigated stony, free-draining Balmoral soil for three crop grazing systems: fodder beet (FB); early-sown kale (EK); and late-sown kale with oats grown in sequence (LK). There were two replicates of each treatment, with 35-58 cows per treatment group. Allocations of crop and supplements ( $\mathrm{kg} \mathrm{DM} /$ cow/day) were: $\mathrm{FB}, 8 \mathrm{~kg}$ fodder beet $+6 \mathrm{~kg}$ grass baleage; EK, $14 \mathrm{~kg}$ kale $+3 \mathrm{~kg}$ barley straw; LK, $11 \mathrm{~kg}$ kale $+5 \mathrm{~kg}$ green chop oat baleage. Pre-grazing crop DM yield ( $\mathrm{t} \mathrm{DM} / \mathrm{ha}$ ) was higher in FB (20.1) than EK (14.6) and LK (12.9). DM utilisation was high in all treatments averaging $99.6 \%, 90.5 \%$ and $87.1 \%$ for FB, EK and LK, respectively. Body condition score change over the 8-week winter-feeding period was similar for cows offered FB $(+0.76)$, EK $(+0.66)$ and LK $(+0.76)$. Allocation of feed quantity is more important in determining BCS gain than the type of crop and supplement fed.
\end{abstract}

Keywords: Brassica oleracea L., Beta vulgaris L., metabolisable energy

\section{Introduction}

Many pregnant, non-lactating dairy cows from South Island dairy farms are wintered off the milking platform on forage crops grazed in situ (Judson et al. 2010). The aim in this period is to regain cow body condition, before calving, that was lost during the previous lactation. The forage brassica kale (Brassica oleracea L.) has been widely used because of its high dry matter (DM) yield and quality relative to pasture in winter (Brown et al. 2007; Rugoho et al. 2014). However, there are concerns that cows may not regain adequate body condition when fed kale (Greenwood et al. 2011; Rugoho et al. 2014); consequently alternative crops (e.g. fodder beet, Beta vulgaris L.) and cropping sequences (de Ruiter et al. 2009) have been proposed.
The research reported here is part of package of work conducted in the Pastoral 21 Phase 2 programme on the production and environmental performance of outdoor wintering systems in Canterbury. The objective of this study was to compare crop DM yield and quality, DM utilisation and body condition score (BCS) gain of nonlactating pregnant dairy cows grazing an early-sown kale crop, a late-sown kale crop grown in sequence with oats, and fodder beet.

\section{Methods}

Experimental site, design and crop management

The experiment was conducted over winter in consecutive years (2012 and 2013) at Lincoln University's farm, Ashley Dene, located near Burnham, Canterbury $\left(-43.65^{\circ} \mathrm{N} 172.33^{\circ} \mathrm{E}\right)$, with approval of the Lincoln University Animal Ethics Committee (AEC 473, AEC 523). The soil type was a stony, free-draining Balmoral soil with low water holding capacity. The site was converted from dryland pasture to irrigated dairy support land in 2011. The experimental design was two replicates of three forage crops: early-sown kale (EK); late-sown kale with oats (Avena sativa L.) in sequence after kale is grazed (LK); and fodder beet (FB). The EK and LK experimental unit consisted of 3 ha of the kale and 2 ha of perennial ryegrass (Lolium perenne $\mathrm{L}$ ). The FB experimental unit consisted of 1 ha of fodder beet and 2 ha of perennial ryegrass. The areas allocated to each treatment reflected DM yield expectations and were calculated to accommodate approximately 50 cows in each experimental unit over an 8-week winter feeding period. The perennial ryegrass area was used for transition feeding of cows onto the forage crop at the start of winter feeding, and harvested for grass baleage in the remainder of year. The details of crop management of all three treatments are shown in Table $1(2011 / 2012)$ and Table $2(2012 / 2013)$. No oat cereal was sown in the first year, as the experimental programme did not begin until October 2011. Areas of kale were in the same place in consecutive years. Each 


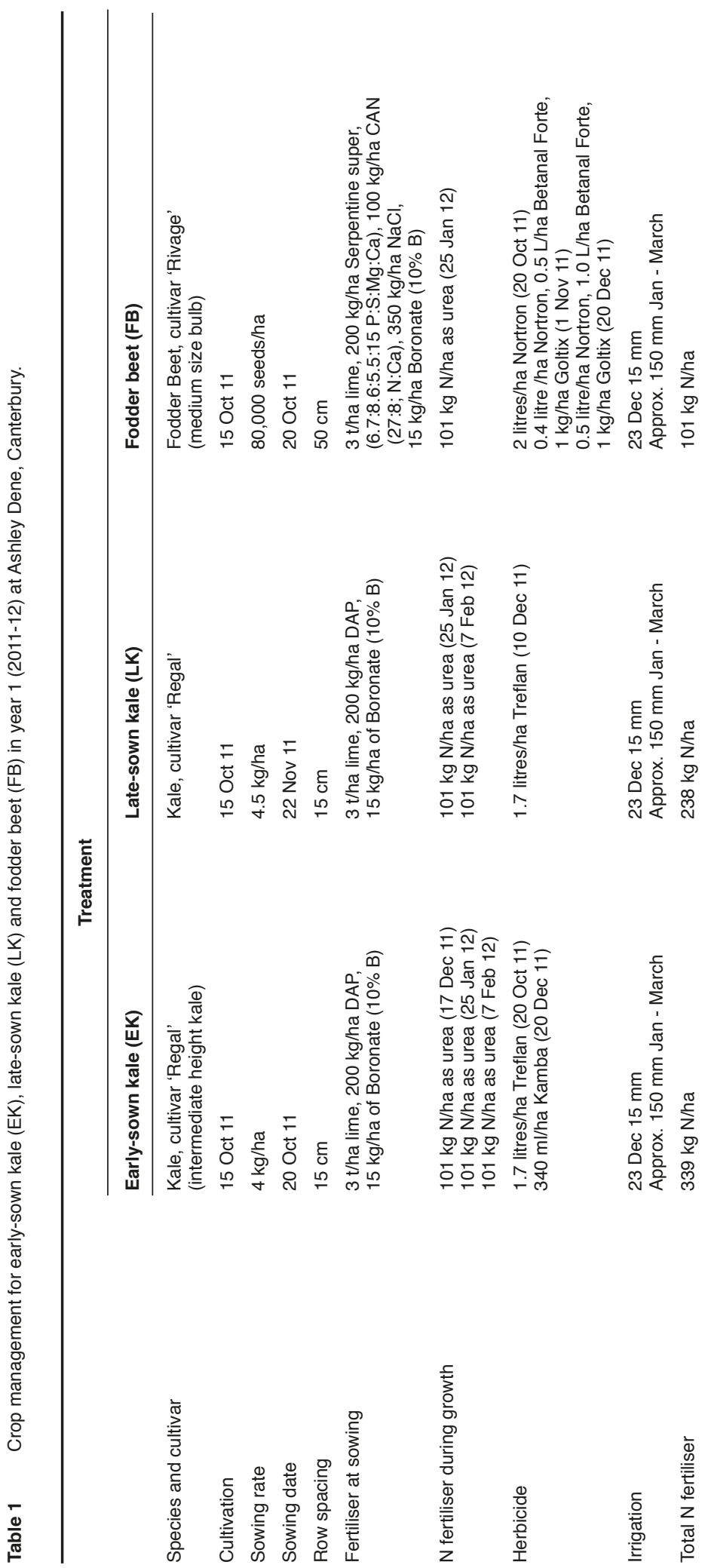

year, fodder beet was sown into newly cultivated blocks of grass.

\section{Animals and feeding}

In both years, 300 multiparous non-lactating, Friesian $\times$ Jersey cross cows were blocked according to BCS (4.5, range 3.56.0 ; 4.3, range 3.5-5.5, 2012 and 2013, respectively), liveweight (520 kg, range 375-645; $501 \mathrm{~kg}$, range $396-640 \mathrm{~kg}$ ), calving date (28 August, range 2 August-12 October; 26 August, range 3 August-12 October), and age (4.1 years, range $2-9$ years; 4.0 years, range 2-9 years) and allocated randomly to two replicates of EK, LK and FB. In 2012, due to lower DM yield of fodder beet, there were 35 cows allocated to each FB treatment group and 57 and 58 cows to EK and LK, respectively. In 2013, there were 50 cows in each treatment group. Crop and supplements were offered to deliver an estimated consumed (taking account of wastage) intake of $160 \mathrm{MJME} / \mathrm{cow} /$ day: EK, 14 $\mathrm{kg}$ kale $+3 \mathrm{~kg}$ barley straw; LK, $11 \mathrm{~kg}$ kale $+5 \mathrm{~kg}$ green chop oat baleage; FB, $8 \mathrm{~kg}$ fodder beet + $6 \mathrm{~kg}$ grass baleage; all in $\mathrm{kg} \mathrm{DM} /$ cow/day. The cows were sourced from the Lincoln University Dairy Farm herd that had been managed under standard dairy farm practice with lactation finishing around 20 May. Cows grazed forage crops from 1 June to 30 July (60 days) in 2012 and 30 May to 26 July (54 days) in 2013, before returning to the milking platform. Cows were offered supplement at 7:00-8:00 h and access to a fresh forage break at 9:00-10:00 $\mathrm{h}$ each day, with grazing areas separated by electric fencing. Supplement was offered to cows in an area of the forage crop that had previously been grazed. Cows were transitioned onto the crop over 7 days for EK and LK and 14 days for $\mathrm{FB}$, increasing the crop offered by 0.5 to $2 \mathrm{~kg} \mathrm{DM}$ per cow per day and adjusting 
pasture and supplement allowances to meet daily energy requirements. The supplements were chosen as representative of dairy industry practices with forage crops. Barley straw (Hordeum vulgare L.), a low crude protein (CP) supplement, is typically fed with kale in wintering systems. Grass baleage, a moderate CP supplement, is often fed with fodder beet, a low $\mathrm{CP}$ forage, to raise the overall $\mathrm{CP}$ content of the diet. Oat baleage, grown as part of the crop rotation in the EK system, was fed back with the kale during winter.

\section{Crop and supplement measurements}

Pre-grazing crop DM yield was determined prior to the start of winter grazing, and then at weekly intervals, by harvesting pregrazed material to ground level in five randomly positioned $1 \mathrm{~m}^{2}$ quadrats in kale and three randomly positioned $6 \mathrm{~m}^{2}$ quadrats ( 2 rows $\times$ $3 \mathrm{~m}$ row length) in fodder beet. The area sampled was representative of what cows would graze the following week. The fresh weight of the bulked sample was recorded in the field, and two subsamples of four plants of kale and two plants of fodder beet were separated into leaf and stem or bulb, and weighed. For kale, leaf lamina (containing midrib) was cut at the point where lamina joins the petiole, and the remaining petiole was included in the stem fraction. For fodder beet, the leaf petiole was included in the leaf fraction. One subsample was oven-dried at $90^{\circ} \mathrm{C}$ for $48 \mathrm{~h}$ for determination of $\mathrm{DM} \%$ and $\mathrm{DM}$ yield. The DM yield was then used to determine the break size for each forage crop. The second subsample of crop, and a subsample of each supplement, was freeze-dried, ground to $1 \mathrm{~mm}$, and scanned by near infra-red spectrophotometer (NIRS, NIRSystems 5000, Foss, Maryland, USA) to predict digestible organic matter in DM (DOMD), CP, soluble

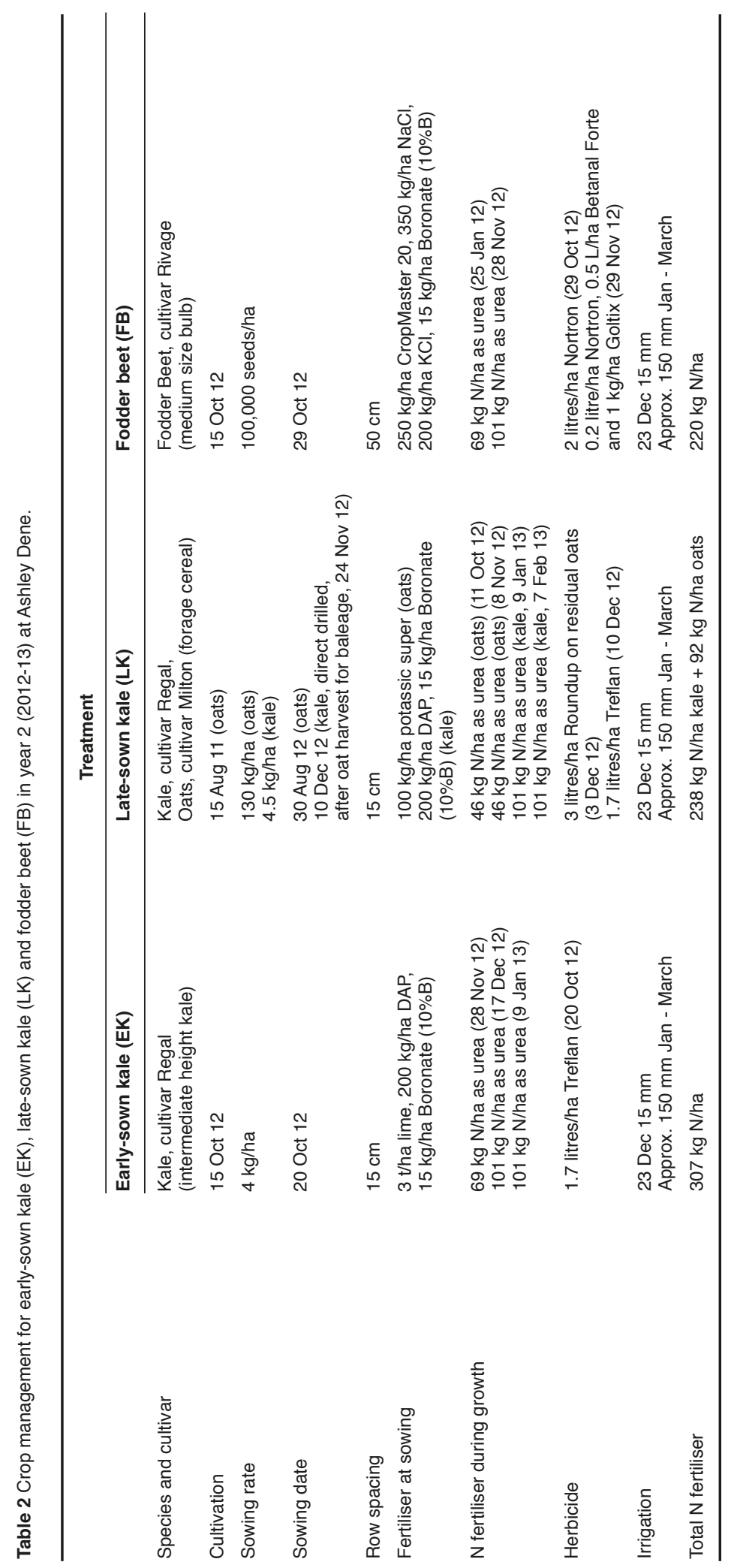


sugars and starch (SSS) and neutral detergent fibre (NDF). Metabolisable energy (ME) was calculated as MJME/kg DM $=0.16 \times$ DOMD (CSIRO 2007). The $\mathrm{DM}$ yield of the oats was determined on 10 randomly positioned $0.5 \mathrm{~m}^{2}$ quadrats from each plot immediately prior to baleage harvest on 23 November 2012.

Post-grazing DM yield was determined by harvesting residual kale and fodder beet every week in three randomly placed $1 \mathrm{~m}^{2}$ quadrats in areas that had been grazed the previous week. All kale or fodder beet residue within the quadrat was collected, and washed to remove soil, faeces and dead material. The sample was weighed fresh, oven-dried at $90^{\circ} \mathrm{C}$ for $48 \mathrm{~h}$ and re-weighed. From these data, DM utilisation $(\%$, pre DM yield - post DM yield/pre DM yield $\times 100$ ) was determined and used to estimate apparent intake of crop ( $\mathrm{kg} \mathrm{DM} / \mathrm{cow} /$ day, \% utilisation $\times$ allowance). Utilisation of supplement was recorded on two occasions in each year by weighing the mass of straw or baleage in six $1 \mathrm{~m}^{2}$ areas in each paddock before it was harvested by cows, returning it to the ground, and then recovering and weighing remaining straw or baleage one day later.

\section{Animal measurements}

Body condition score (0-10 scale) (Roche et al. 2004) of all cows was recorded at the start and end of each winter feeding period.

\section{Statistical analysis}

The effect of crop type on DM yield, DM utilisation and BCS gain over the winter grazing period was analysed by one-way ANOVA for each year with the experimental unit being the mean value averaged across plant samples or cows in each replicate (six experimental units).

\section{Results}

Pre-grazing crop DM yield in 2012 and 2013 was greater in FB than EK and LK (Table 3). The proportion of leaf was lower in FB than EK and LK in both years. The oat crop preceding late-sown kale in 2013 yielded $7.5 \mathrm{t} \mathrm{DM} /$ ha. The CP percentage of crop (total plant) did not exceed $13.0 \%$ of DM for any crop and was not significantly different between crops (Table 3). The ME content was higher for EK and LK than FB, due to greater DOMD of kale. Neutral detergent fibre was higher and soluble sugars and starch (SSS) lower in EK and LK than FB. Barley straw had lower CP\% and ME (4.4\%, 6.1 MJME/ $\mathrm{kg} \mathrm{DM})$ than oat baleage $(13.8 \%, 10.5 \mathrm{MJ} \mathrm{ME} / \mathrm{kg} \mathrm{DM})$ or ryegrass baleage (12.6\%, $11.3 \mathrm{MJME} / \mathrm{kg} \mathrm{DM})$. Crop DM utilisation was lower in EK and LK than FB, although all values were high $(>85 \%)$ (Table 3 ). Estimates of DM utilisation of supplement were 51, 65 and $86 \%$ for barley straw (EK), oat silage (LK) and grass baleage (FB), respectively, giving total apparent daily DM intake ( $\mathrm{kg} \mathrm{DM} / \mathrm{cow} /$ day, averaged over two years) of crop plus supplement of 14.2 (EK), 12.8 (LK) and 13.1 (FB). Body condition score did not differ between treatments at the start of the experiment $(2012=4.5 ; 2013=4.3)$. The gain in BCS in 2012 (BCS units average $=0.74)$ and 2013 (BCS units average $=0.72$ ) was not significantly different among crops (Table 3).

Table 3 Crop DM yield (pre- and post- grazing) and utilisation, crop composition (MJME, and percentage of crude protein, neutral detergent fibre and soluble sugars and starch) and body condition score gain of cows for an eight week period during winter grazing for early-sown kale (EK), late-sown kale (LK) or fodder beet (FB) in 2012 and 2013. Data on crop $\mathrm{DM}$ yield and composition are averaged across samples collected throughout the grazing period.

\begin{tabular}{|c|c|c|c|c|c|c|c|c|c|c|}
\hline & \multicolumn{5}{|c|}{2012} & \multicolumn{5}{|c|}{2013} \\
\hline & EK & LK & FB & $P$ value & LSD & EK & LK & FB & $P$ value & LSD \\
\hline \multicolumn{11}{|l|}{ Crop DM yield } \\
\hline Pre-grazing (t DM/ha) & 15.5 & 14.0 & 18.5 & 0.11 & 4.49 & 13.8 & 11.9 & 21.8 & $<0.01$ & 0.39 \\
\hline Post-grazing (t DM/ha) & 1.7 & 2.0 & 0.1 & 0.02 & 1.07 & 1.1 & 1.3 & 0.1 & 0.07 & 1.15 \\
\hline$\%$ DM utilisation & 88.8 & 85.5 & 99.5 & 0.03 & 8.36 & 92.2 & 88.8 & 99.7 & 0.43 & 8.66 \\
\hline \multicolumn{11}{|l|}{ Crop composition } \\
\hline$\% \mathrm{DM}$ & 15.1 & 14.6 & 18.1 & 0.01 & 1.52 & 12.9 & 12.8 & 15.0 & 0.03 & 1.46 \\
\hline$\%$ leaf & 16.4 & 18.8 & 4.3 & $<0.01$ & 0.76 & 15.2 & 20.7 & 6.0 & $<0.01$ & 2.45 \\
\hline ME (MJ ME/kg DM) & 12.8 & 12.9 & 12.2 & $<0.01$ & 0.12 & 12.7 & 12.8 & 12.1 & 0.02 & 0.26 \\
\hline$\%$ Crude protein & 12.5 & 12.4 & 10.4 & 0.11 & 2.34 & 12.6 & 12.6 & 10.8 & 0.24 & 3.1 \\
\hline$\%$ Neutral detergent fibre & 26.4 & 27.2 & 20.6 & 0.01 & 4.16 & 26.2 & 27.5 & 20.5 & 0.02 & 4.25 \\
\hline$\%$ Water soluble carbohydrate & 46.2 & 44.8 & 57.0 & 0.03 & 7.42 & 46.7 & 44.1 & 56.4 & 0.03 & 7.26 \\
\hline \multicolumn{11}{|l|}{ Animal } \\
\hline Body condition score gain & 0.70 & 0.77 & 0.74 & 0.84 & 0.34 & 0.62 & 0.74 & 0.78 & 0.51 & 0.41 \\
\hline
\end{tabular}




\section{Discussion}

The DM yield of fodder beet of 18.5 and $21.8 \mathrm{t} \mathrm{DM} /$ ha in 2012 and 2013, respectively, are within the range of 11 to $27 \mathrm{t} \mathrm{DM} /$ ha reported in an early study (Goh \& Magat 1989) but less than the average DM yield of $32.8 \mathrm{t} \mathrm{DM} /$ ha found in a recent study by Chakwizira et al. (2012). The lower DM yield may reflect the cultivar used ('Rivage' vs 'Colesse') and soil type (Balmoral stony loam vs Waimakariri sandy loam) between the current study and that of Chakwizira et al. (2012). The DM yield of fodder beet in 2012 was lower than expected. This was caused by a lower than intended established plant population in the first year $(6$ plants $/ \mathrm{m}^{2}$ ) compared with the ideal of $8-10$ plants $/ \mathrm{m}^{2}$, combined with soil water stress during December and January resulting from inadequate irrigation frequency.

The DM yield of EK averaged 14.6 t DM/ha and is at the higher end of DM yields reported by Judson \& Edwards (2008) from a survey of dryland and irrigated kale crops on Canterbury dairy farms. Consistent with Brown et al. (2007), sowing kale later (LK: late Novearly December) reduced the DM yield by $1.5-1.9 \mathrm{t}$ $\mathrm{DM} /$ ha compared to $\mathrm{EK}$, presumably reflecting lower thermal time available before the end of the season. However, sowing later enabled an oat crop to be sown in late August after the kale crop had been grazed, and harvested as green chop baleage in late November-early December; this resulted in a greater total annual DM yield for LK (19.4 t DM/ha) than EK (13.8 t DM/ha) in the same time period. Moreover, this was achieved with only $23 \mathrm{~kg} \mathrm{~N} / \mathrm{ha}$ more $\mathrm{N}$ fertiliser (330 vs $307 \mathrm{~kg} \mathrm{~N} /$ ha), with calculated efficiencies of the use of $\mathrm{N}$ fertiliser for DM yield being $58 \mathrm{~kg} \mathrm{DM} / \mathrm{kg} \mathrm{N}$ and $44.9 \mathrm{~kg} \mathrm{DM} /$ $\mathrm{kg} \mathrm{N}$ for LK and EK, respectively. The $\mathrm{N}$ efficiency results indicate the potential of the kale-oat system to extract and use available $\mathrm{N}$ more effectively than early sown kale crops, with ongoing studies examining the potential of this system to reduce nitrate leaching. It is noteworthy, however, that efficiency values for EK and LK were considerably lower than that achieved with FB ( $99 \mathrm{~kg} \mathrm{DM} / \mathrm{kg} \mathrm{N})$, thus demonstrating the high capability of FB to yield with low $\mathrm{N}$ fertiliser inputs.

\section{DM utilisation and apparent DM intake}

DM utilisation was high $(>85 \%)$ for all crops with almost complete consumption of fodder beet $(99.6 \%)$. Similar or higher DM utilisation rates on kale have been reported from pre- and post-grazing measurements in a farm survey (Judson \& Edwards 2008) and from experimental studies (Greenwood et al. 2011; Rugoho et al. 2014). Little comparable data are available on DM utilisation of fodder beet; however, the values are higher than the $82 \%$ utilisation of swedes reported by Thompson \& Stevens (2012). The high levels of DM utilisation, combined with high consumption of some but not all supplement gave apparent total DM intake values ranging from 12.9 to $14.2 \mathrm{~kg}$ DM. Similar DM intakes were obtained for cows allocated kale at $14 \mathrm{~kg} \mathrm{DM}$ and $3 \mathrm{~kg}$ barley straw based on individual animal measurements using alkane analyses (Rugoho et al. 2014). While there is some debate around the intake potential of cows grazing forage crops in late lactation (Greenwood et al. 2011), the results indicate the high DM intake potential of low NDF forages in late pregnancy.

\section{Body condition score gain}

The gain in BCS over the winter feeding period exceeded 0.5 BCS units but was not significantly different among forage treatments. Greenwood et al. (2011) reported lower BCS gain when kale was offered at 11 (0.23 units) compared with $14 \mathrm{~kg} \mathrm{DM} / \mathrm{cow} /$ day (0.64 units). However, in their case the supplement only added $28 \mathrm{MJ}$ (3 kg barley straw) compared with the 53 MJME (5 kg oat baleage) supplemented to LK in the current study. When apparent DM intake data are combined with energy composition data for forage and supplements, estimated total ME intake (MJME/ cow/day) over the 8-week period was similar among forage crops $(168,157$, and 155 for EK, LK and FB, respectively). The estimated energy requirements for maintenance, pregnancy and activity in late gestation are 1.05 MJME $/ \mathrm{kg} \mathrm{LW}^{0.75}$ (Roche et al. 2005) which equates to $113 \mathrm{MJME} / \mathrm{d}$ for a $510 \mathrm{~kg}$ cow (starting average for two years). Using the actual condition score changes averaged over two years, and assuming a net energy content of $19 \mathrm{MJ} / \mathrm{kg}$ live weight gain with an efficiency of ME utilisation of 0.53 for non-lactating cows (AFRC 1993), an additional 14, 16 and 16 MJME/ cow/day were required for cows on EK, LK and FB, respectively, making the total ME requirements of 127 , 129 and 129; such values are 44, 28, and 26 less than the estimated ME intakes for EK, LK and FB, respectively. The disparity between estimated ME intake and calculated ME requirements for BCS on winter forage crops has been highlighted previously (Greenwood et al. 2011), and may be related to a range of factors, including: overestimation of ME, underestimation of the energy requirements for maintenance and live weight gain (Roche et al. 2005; Mandok et al. 2013), increased intake demand to meet metabolisable protein requirements on low CP crops (Westwood \& Mulcock 2012), and limitations to performance associated with consumption of anti-nutritional compounds such as S-methylcysteine sulphoxide (SMCO) in kale (Barry \& Manley 1985). Inaccuracy of ME value may arise due to large variation between actual and predicted digestibility at high levels of intake and overestimation of the gross energy content of forage crops such as kale and fodder beet which have low crude protein and 
high water soluble carbohydrate concentrations (Clark et al. 1987). High base assumptions for gross energy values coupled with reduced digestibility of feeds in ruminants in cold environments (Ketelaars \& Tolkamp 1992; Mairon \& Christopherson 1992) could result in prediction of $\mathrm{ME}$ requirements that are lower than actual values.

\section{Conclusion}

The research confirms that in non-lactating, pregnant cows both brassica and fodder beet crops with supplements can meet the requirements for BCS gain provided that feed allocation and utilisation are appropriate. ME intakes after allowing for wastage at feeding out approaching $150 \mathrm{MJME} / \mathrm{cow} / \mathrm{day}$ will ensure that cows gain in excess of $0.5 \mathrm{BCS}$ units over an 8 -week winter feeding period.

\section{ACKNOWLEDGEMENTS}

This work was conducted through the Pastoral 21 Programme (C10X1117), jointly funded by the Ministry of Business, Innovation and Employment, DairyNZ Inc, Fonterra, Beef + Lamb New Zealand and the Dairy Companies Association of New Zealand. We thank Melanie Allen, Helen Hague, Brenda Lynch, Innocent Rugoho, Jeff Curtis, Jonathan Curtis, Shane Malley, and Willem Erasmus for technical assistance during the project.

\section{REFERENCES}

AFRC. 1993. Energy and protein requirements of ruminants. An advisory manual prepared by the AFRC Technical Committee on responses to nutrients. $\mathrm{CAB}$ International, Wallingford, United Kingdom.

Barry, T.N.; Manley, T.R. 1985. Responses to oral methionine supplementation in sheep fed kale (Brassica oleracea) diets containing S-methylcysteine sulphoxide. British Journal of Nutrition 54: 753-761.

Brown, H.E.; Maley, S.; Wilson, D.R. 2007. Investigations of alternative kale management: Production, regrowth and quality from different sowing and defoliation dates. Proceedings of the New Zealand Grassland Association 69: 29-33.

Chakwizira E.; Maley S.; George, M.; Hubber, R.; Morton, J.; Stafford, A. 2012. Effects of potassium, sodium and chloride fertilisers on yield and mineral composition of fodder beet. Proceedings of the 5th Australasian Dairy Science Symposium, Melbourne, Australia. pp 431-434.

Clark, P.; Givens D.I.; Jeannie, M.B. 1987. The chemical composition, digestibility and energy value of fodder-beet roots. Animal Feed Science and Technology 18: 225-231.
CSIRO. 2007. Nutrient requirements of domesticated ruminants. pp 8. Eds. Freer, M.; Dove, H.; Nolan, J.V. Collingwood, Australia.

de Ruiter, J.M.; Fletcher, A.; Maley, S.; Sim, R.; George, M. 2009. Aiming for $45 \mathrm{t} / \mathrm{ha}$ per annum: yield of supplementary feed crops grown in sequences designed for maximum productivity. Proceedings of the New Zealand Grassland Association 71:107-116.

Goh, K.M.; Magat, S.S.1989. Sodium chloride increases yield of fodder beet (Beta vulgaris L.) in two New Zealand soils. New Zealand Journal of Agricultural Research 32: 133-137.

Greenwood, S.L.; Dalley, D.E.; Purdie, N.G.; Rugoho, I.; Bryant, R.H.; Edwards, G.R. 2011. Brief communication: Comparison of the performance of dairy cows offered energy supplements prior to drying off and kale at high and low allowance during the dry period in winter. Proceedings of the New Zealand Society of Animal Production 71: 33-36.

Ketelaars, J.J.M.H.; Tolkamp, B.J. 1992. Toward a new theory of feed intake regulation in ruminants 1. Causes of differences in voluntary feed intake: critique of current views. Animal Production Science 30: 269-296.

Judson, H.G.; Edwards G.R. 2008. Survey of management practices of dairy cows grazing kale in Canterbury. Proceedings of the New Zealand Grasslands Association 70: 249-254.

Judson, H.G.; Dalley, D.E.; Edwards, G.R.; Stephens, D.R.; Gibbs, S.J. 2010. Improving winter feeding outcomes in South Island dairy herds. pp 137143. In: Proceedings of the 4th Australasian Dairy Science Symposium. Eds. Edwards, G.R.; Bryant, R.H. Lincoln University, Christchurch 31 August-2 September.

Mandok, K.S.; Kay, J.K.; Greenwood, S.L.; Edwards, G.R.; Roche, J.R. 2013. Requirements for zero energy balance of nonlactating, pregnant dairy cows fed fresh autumn pasture are greater than currently estimated. Journal of Dairy Science 96: 4070-4076.

Miaron J.O.; Christopherson R.J. 1992. Effect of prolonged thermal exposure on heat production, reticular motility, rumen-fluid and -particulate passage rate constants, and apparent digestibility in steers. Canadian Journal of Animal Science 72: 809819.

Roche, J.R.; Dillon, P.G.; Stockdale, C.R.; Baumgard, L.H.; VanBaale, M.J. 2004. Relationships among international body condition scoring systems. Journal of Dairy Science 87: 3076-3079.

Roche, J.R.; Kolver, E.S.; Kay, J.K. 2005. Influence of precalving feed allowance on periparturient metabolic and hormonal responses and milk production in grazed dairy cows. Journal of Dairy Science 88: 677-689. 
Rugoho, I.; Gibbs, S.J.; Edwards, G.R. 2014. Dry matter intake and body condition score gain of dairy cows offered kale and grass. New Zealand Journal of Agricultural Research 57: 110-121.

Thompson, B.R.; Stevens, D.R. 2012. A comparison of the intake of cows grazing swedes and kale and consequent condition score change. Proceedings of the New Zealand Grassland Association 74: 63-67.
Westwood, C.T.; Mulcock. 2012 Nutritional evaluation of five species of forage brassica. Proceedings of New Zealand Grassland Association 74: 31-38. 